\title{
ESP vs EFL; The Case of Learning Strategy Use in an Iranian Context
}

\author{
Aliasghar Ahmadishokouh ${ }^{1}$, Ali Derikvand ${ }^{2}$ \\ ${ }^{1}$ Language Department, Faculty of Humanitarian, Tarbiat Modares University, Tehran, Iran \\ ${ }^{2}$ Language Department, Islamic Azad University, Khoramabad, Iran
}

Email address:

Ahmadishokouhtmu@gmail.com (A. Ahmadishokouh)

\section{To cite this article:}

Aliasghar Ahmadishokouh1, Ali Derikvand. ESP vs EFL; The Case of Learning Strategy Use in an Iranian Context. International Journal of Language and Linguistics. Vol. 3, No. 6, 2015, pp. 440-447. doi: 10.11648/j.ij11.20150306.28

\begin{abstract}
Learning strategies and learner strategies known as two key variables have affected language learning. These strategies also play a sensitive role in the learning context and in the learner's internal processing preferences. The present study attempted to investigate language learning strategies used by Iranian EFL and ESP learners. The study sample consisted of 66 language learners (33 EFL learners and 33 ESP learners.). The research instrument was the Strategy Inventory for Language Learning (SILL) questionnaires (Oxford, 1990a), which is a standardized measure with versions for English as a second language (ESL) students and students of a variety of other languages. Independent-sample T-test was used to compare the means of ESP and EFL learners. The results of the study showed that there is a significant difference between Iranian EFL and ESP learners in terms of employing learning strategies. Furthermore, in order to find the difference within each group in using language learning strategies, repeated-measures on way ANOVA was used. The results of the study showed that there is a significant difference within each group of language learners (ESP and EFL) when it comes to employing learning strategies.
\end{abstract}

Keywords: Language Learning Strategies, EFL Learners, ESP Learners

\section{Introduction}

Different people employ various techniques to learn different things. Scholars use the term "learning strategies" to introduce this phenomenon. However, the terminology of this phenomenon is not always unified, with some researchers using the terms "learner strategies" (Wendin\& Rubin, 1987), others "learning strategies" (O'Malley \&Chamot, 1990; Chamot\& O'Malley, 1994), and still others "language learning strategies" (Oxford, 1990a, 1996). Learning strategies and learner strategies as two key variables affecting language learning, are no longer new terms to many teachers and educators. Today, learning strategies are becoming widely recognized through education in general and language learning in particular. These strategies are "specific behaviors or thought processes" (Oxford, 1990a) that language learners can employ to promote their language learning. Learning strategies are defined as "specific actions, behaviors, steps, or techniques such as seeking out conversation partners, or giving oneself encouragement to tackle a difficult language task used by students to enhance their own learning" (Scarcella \& Oxford, 1992, p. 63). According to Oxford
(2003), language learningstrategies among the main factors that help determine how and how well our language learners learn a second or foreign language. Oxford (1990) believed that appropriate language learning strategies enhance proficiency and greater self-confidence. Therefore, to promote students' language learning and to facilitate learner autonomy, language-learning strategies are key factors for teachers and instructors that should receive enough attention. Chamot (2005, p. 112) defines learning strategies broadly as "procedures that can facilitate a learning task." According to her, strategies are most often "conscious and goal-driven, especially in the beginning stages of tackling an unfamiliar language task" (ibid). In a rather similar vein, Cohen (2012) defined language learning strategies as "thoughts and actions, consciously chosen and operationalized by language learners, to assist them in carrying out a multiplicity of tasks from the very onset of learning to the most advanced levels of targetlanguage performance" (p. 136).

In addition, supporting the importance of learning strategies, Chamot (2005) maintains that learning strategies in second language learning are important for two major reasons. First, by examining the strategies used by language 
learners during the language learning process, we gain insights into the metacognitive, cognitive, social, and affective processes involved in language learning. The second reason supporting research into language learning strategies is that we can teach less successful language learners new strategies, thus helping them become better language learners (Grenfell \& Harris, 1999). However, the concept of strategy is not always perfectly clear due to the various ways in which strategies have been examined in research and presented in language teaching materials.

Many experts believe that language learners could benefit from employing strategies to compensate for what they do not know or are unable to perform in the language learning. Supporting language learning strategies, Goh (2013) suggests that by employing strategies language learners can attain their learning potential and become individuals who could learn and use language flexibly and independently. He also argues that language learners use strategies to manage their overall learning of the language; perform tasks related listening, speaking, reading and writing; solve specific problems during oral communication; learn vocabulary and grammar; and last but not least, make their efforts at learning and using a second language easier, more productive, and more enjoyable.

Goh (2013, p. 69) further added that by employing strategies, "language learners could become more selfregulated in their own learning by making decisions about how and when to plan, monitor, and evaluate what they learn and the ways they learn".

However, numerous studies and extensive research have addressed the goal of understanding and determining the range and type of learning strategies used by language learners and the differences in learning strategy use between monolingual and bilingual language learners. To the best of our knowledge, there have been no studies focusing yet on language learning strategies used by bilingual and trilingual language learners in Iran. Thus, the present study attempted to shed more light on language learning strategies used by Iranian ESP and EFL learners.

\subsection{Statement of the Problem}

Learners' learning strategies have been extensively used by different scholars in different contexts. However, it seems that the use of learning strategies by ESP and EFL learners has not been investigated appropriately. As in the context of Iran, these two groups of English learners are wide spread, so, familiarity with their learning strategy preference seems to be of much significance. However, it is not known whether there is a difference between the use of learning strategies among Iranian ESP and EFL learners.

\subsection{Research Questions}

In order to carry out this study the following research questions were raised:

1. Is there any significant difference between Iranian ESP and EFL learners in terms of employing languagelearning strategies?
2. Is there any significant difference among the Iranian EFL learners, in using language-learning strategies?

3. Is there any significant difference among the Iranian ESP learners, in terms of employing language-learning strategies?

\subsection{Research Hypotheses}

This study aimed at investigating these hypotheses:

1. There is no significant difference between Iranian ESP and EFL learners in terms of employing languagelearning strategies.

2. There is no significant difference among the Iranian EFL learners, in using language-learning strategies.

3. There is no significant difference among the Iranian ESP learners, in terms of employing language-learning strategies.

\subsection{Significant of the Study}

The findings of the present study have both theoretical and practical significance for applied linguists, teachers, and EFL and ESP learners. Teachers' familiarity with EFL and ESP learners' learning strategies help them to design appropriate materials for teaching English language effectively. And also the findings of the present study can enhance their knowledge about the differences between learning strategies of ESP and EFL learners.

\subsection{Review of the Related Literature}

Until the mid-1970s, the primary focus of applied linguistics research and field of education was centered on classroom-based language teaching methodology with the possible significance of alternative learning contexts or learner contributions such as motivation, learning styles and language learning strategies largely overlooked. From the mid-1970s, there has been a shift in focus from the methods and products of language teaching to a focus on the language learner, with increasing line of scientific inquiry into how language learners process, store, retrieve, and use target language material. One dimension of this inquiry involved attempts to discover how language learners can manage their own learning and the strategies they employ as a means of enhancing target language competence (Hurd \& Lewis, 2008). Different lists and taxonomies of strategy use have been developedbecause of these inquiries. The net result of these inquiries is the two most influential and comprehensive classifications by researchers who are key figures in the field. First is O'Malley and Chamot's (1985) distinction between metacognitive, cognitive and socio-affective strategies, and the second is Oxford's (1990a) Strategy Inventory for Language Learning (SILL) which consists of two different but related groups of strategies; direct strategies (memory, cognitive and compensation strategies) and indirect strategies (metacognitive, affective and social).Chamot (2005) argues that most descriptive studies have been relied onOxford's (1990a) classification. Cook (2008) states that SILL is a benchmark for strategies research for many years. Hence, 
Oxford's classification of learning strategies as an instrument has been extensively used to gather data on large numbers of language learners (see Cohen, Weaver, \& Li, 1998; OlivaresCuhat, 2002; Oxford, 1990; 1996; Oxford \& Burry-Stock, 1995; Wharton, 2000). The SILL is a standardized measure with versions for English as a second language (ESL) students and students of a variety of other languages, and as such can be used to gather and analyze information about large numbers of students. It has also been used in studies to correlate strategy use with variables such as learning styles, gender, proficiency level, culture, and task (Bedell\& Oxford, 1996; Bruen, 2001; Green \& Oxford, 1995; Oxford, Cho, Leung, \& Kim, 2004; Nyikos\& Oxford, 1993; Oxford \& Burry-Stock, 1995; Wharton, 2000).

Based on Oxford's classification (1990), these strategies can be described as follows:

- Cognitive Strategies-skills that involve manipulation or transformation of the language in some direct way through reasoning, analysis, note taking, functional practice in naturalistic settings, formal practice with structures and sounds, etc.

- Memory Strategies-techniques to help store new information in memory and retrieve it later

- Compensation Strategies-behaviors used to compensate for missing knowledge of some kind such as guessing while listening or reading, or using synonyms or circumlocution while speaking or writing.

- Metacognitive Strategies-behaviors used for centering, arranging, planning, and evaluating one's learning. These strategies are used to provide "executive control" over the learning process.

- Affective Strategies-techniques like self-reinforcement and positive self-talk which help learners gain better control over their emotions, attitudes, and motivations related to language learning.

- Social Strategies-actions involving other people in the language learning process. Examples are questioning, cooperating with peers, and developing empathy.

Later, Brown (2007) divides the strategies into two groups: learning strategies and communication strategies. While learning strategies consist of cognitive, metacognitive and social/affective strategies, compensation and avoidance strategies are seen in the communication strategies group.

Further, Brown (2007) states that learning strategies are concerned with the receptive domain (e.g., reading \& listening) of intake, memory, storage, and recall, while communication strategies are germane to the employment of verbal or nonverbal mechanisms for the productive communication of information.

\section{Methodology}

\subsection{Participant}

66 language learners participated in this study. The participants were 33 ESP learners majoring in management and Elahiat, and 33 EFL undergraduate students majoring in
English Language teaching. Their age was 20 to 25 .

\subsection{Instrument}

The most frequently used method to elicit students' language learning strategies is through filling out questionnaire. One of the most widely used measures in the field of language learning strategiesis Oxford's (1990a) the Strategy Inventory for Language Learning (SILL) (Dörnyei 2005; White, Schramm \&Chamot, 2007). It is a structured questionnaire, aiming to assess how often learners employ specific language learning strategies. Further, it equips teachers with the strategy profile of their students and uncovers to learners the kinds of strategies they have recourse to when learning English as a second or foreign language (Oxford 1990). Hence, in the present study, SILL that is also a likert-type measure was used to elicit information from participants. The questionnairedeveloped by Oxford's (1990) classification has a 50-item version for learners of English as a second or foreign language. The internal consistencyreliability of the SILL, reported by Oxford and Ehrman (1995), is ordinarily in the range of $0.90 \mathrm{~s}$. The 50 -item version has strong predictive and concurrent validity as related to language performance and sensory performance (Borzabadi, 2000). This questionnaire asks language learners to react to a series of strategy descriptions in terms of how often they use the strategies: 1 (never or almost never), 2 (usually not), 3 (sometimes), 4 (often) and 5 (always or almost always). The questionnaire was structured according to the six categories of strategy use. The 50-item version of SILL, used in this study consists of six groups as follows:

- Group A: Memory strategies (9 items)

- Group B: Cognitive strategies (14 items)

- Group C: Compensation strategies (6 items)

- Group D: Metacognitive strategies (9 items)

- Group E: Affective strategies (6 items)

- Group F: Social strategies (6 items)

\subsection{Procedure}

A pilot test was carried out to check the clarity and comprehensibility of the questionnaire. There was a fifteenminute briefing session before administering the questionnaire. Further, the SILL was accompanied by a demographic questionnaire, in which background information about language learners' sex, linguistic background, age, and major was obtained. The data gathered from the participants were coded and entered into SPSS. After converting the data from ordinal to interval, independent sample t-test was run for comparing the means of the two groups on the use of learning strategies and repeated measures ANOVA was used to compare the means of each group on different learning strategies.

\section{Result}

Results of the study including the means of the 
participants on each strategy as inferential statistics, including independent sample t-tests and repeated measures ANOVA are presented in the following tables.

Q1: Is there any significant difference between Iranian ESP and EFL learners in terms of employing languagelearning strategies?

To answer this question the researcher made use of independent sample t-test for comparing the means of ESP and EFL learners, and also descriptive statistics and related bar graph were added to provide a clear picture of differences between two groups as follows:

Table 1. Group Statistics.

\begin{tabular}{llllll}
\hline & status & N & Mean & $\begin{array}{l}\text { Std. } \\
\text { Deviation }\end{array}$ & $\begin{array}{l}\text { Std. Error } \\
\text { Mean }\end{array}$ \\
\hline \multirow{2}{*}{ memory } & EFL & 33 & 3.36 & .478 & .083 \\
& ESP & 33 & 3.12 & .644 & .112 \\
cognitive & EFL & 33 & 3.73 & .590 & .102 \\
compensation & ESP & 33 & 2.93 & .686 & .119 \\
& EFL & 33 & 3.71 & .729 & .126 \\
metacognitive & ESP & 33 & 2.83 & .887 & .154 \\
& EFL & 33 & 4.01 & .511 & .089 \\
affective & ESP & 33 & 3.35 & .931 & .162 \\
& EFL & 33 & 3.47 & .521 & .090 \\
social & ESP & 33 & 2.83 & .789 & .137 \\
& EFL & 33 & 3.81 & .657 & .114 \\
& ESP & 33 & 3.02 & .981 & .170 \\
\hline
\end{tabular}

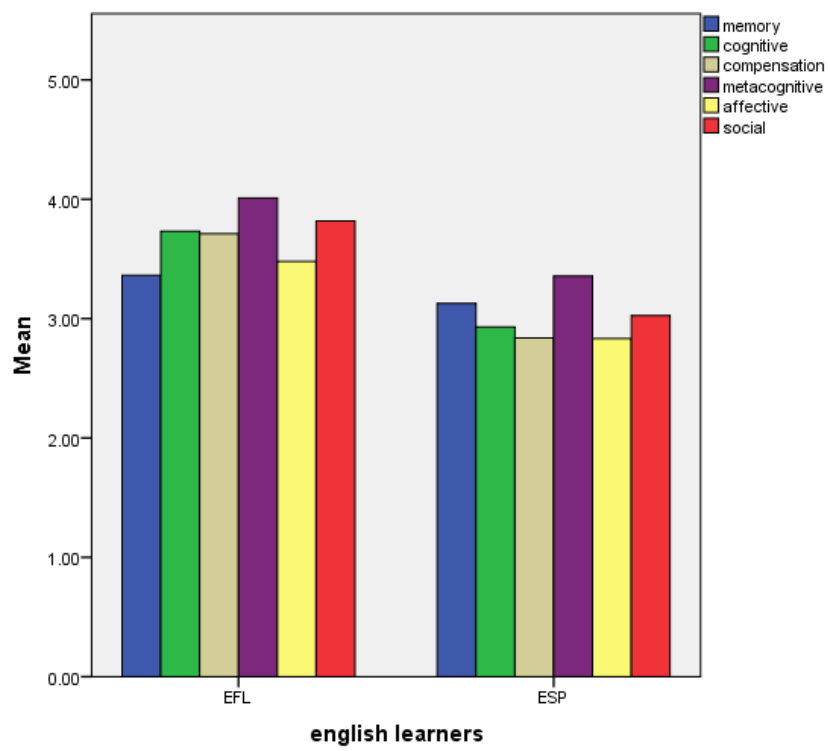

Figure 1. For comparing the means of ESP and EFL learners.

As it can be seen from descriptive statistics table (table1) and its associated bar graph (figure.1), the results show that the means of Iranian EFL learners on all strategies exceed those of ESP learners. In order to see whether the differences are statistically significant, the means of the two groups were compared through independent sample- t-tests.

The results are shown in the following table.

Table 2. T-tests for comparing the means of the groups on learning strategies.

\begin{tabular}{|c|c|c|c|c|c|c|c|c|}
\hline & & \multicolumn{7}{|c|}{$\begin{array}{l}\text { Levene's Test for Equality } \\
\text { of Variances }\end{array}$} \\
\hline & & $\mathbf{F}$ & Sig. & $\mathbf{t}$ & df & Sig. (2-tailed) & $\begin{array}{l}\text { Mean } \\
\text { Difference }\end{array}$ & $\begin{array}{l}\text { Std. Error } \\
\text { Difference }\end{array}$ \\
\hline memory & Equal variances assumed & 4.03 & .059 & 1.68 & 64 & .097 & .23 & .13 \\
\hline cognitive & Equal variances assumed & 1.07 & .304 & 5.08 & 64 & .001 & .80 & .15 \\
\hline compensation & Equal variances assumed & .47 & .491 & 4.37 & 64 & .001 & .87 & .19 \\
\hline metacognitive & Equal variances assumed & 8.30 & .055 & 3.53 & 64 & .001 & .65 & .18 \\
\hline social & Equal variances assumed & 6.16 & .016 & 3.85 & 64 & .001 & .79 & .20 \\
\hline
\end{tabular}

As it could be seen there is no significant difference between the mean scores of the EFL and ESP learners in memory strategy $[\mathrm{T}=1.68, \mathrm{df}=64, \mathrm{p}=0.09>0.05]$. But, there is a significant difference between the mean scores of the EFL and ESP learners in cognitive strategy $[\mathrm{T}=5.08, \mathrm{df}=$ 64, $\mathrm{p}=0.001<0.05]$. Moreover, there is a significant difference between the mean scores of the EFL and ESP learners in compensation strategy $[\mathrm{T}=4.37, \mathrm{df}=64, \mathrm{p}=.001<$ 0.05] .Furthermore, there is a significant difference between the mean scores of the EFL and ESP learners in metacognitive strategy $[\mathrm{T}=3.53, \mathrm{df}=64, \mathrm{p}=0.001<$ 0.05].The results also show that there is a significant difference between the mean scores of the EFL and ESP learners in affective strategy $[\mathrm{T}=3.92, \mathrm{df}=64, \mathrm{p}=.001<$ 0.05], and also, there is a significant difference between the mean scores of the EFL and ESP learners in social strategy $[\mathrm{T}=3.85, \mathrm{df}=64, \mathrm{p}=.001<0.05]$. Therefore the first null hypothesis is rejected and it could be argued that there is a significant difference between Iranian ESP and EFL learners in terms of employing learning strategies.

Q2: Is there any significant difference among the Iranian EFL learners, in using language-learning strategies?

In order to answer this question, Repeated-measures one way ANOVA was run for comparing the means of EFL learners on learning strategies. The results of the repeated measures ANOVA with descriptive statistics and related bar graph for providing a visual show of the results, are as follows:

Table 3. Descriptive Statistics.

\begin{tabular}{llll}
\hline & Mean & Std. Deviation & N \\
\hline memory & 3.36 & .478 & 33 \\
cognitive & 3.73 & .590 & 33 \\
compensation & 3.71 & .729 & 33 \\
metacognitive & 4.01 & .511 & 33 \\
affective & 3.47 & .521 & 33 \\
social & 3.81 & .657 & 33 \\
\hline
\end{tabular}




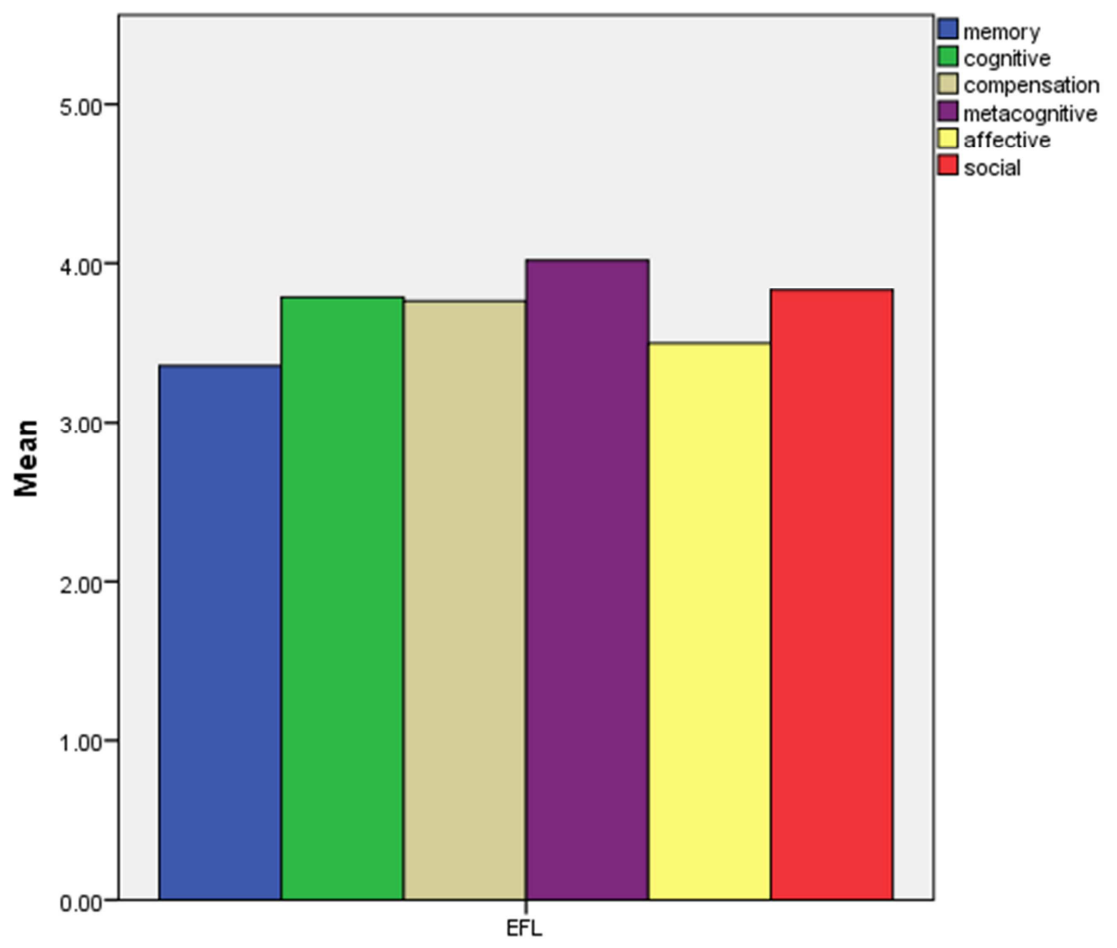

EFL learners

Figure 2. Means of learning strategies for EFL learners.

Table 4. Mauchly's Test of Sphericity.

\begin{tabular}{|c|c|c|c|c|c|c|c|}
\hline \multicolumn{8}{|l|}{ Measure: MEASURE_1 } \\
\hline \multirow{2}{*}{ Within Subjects Effect } & \multirow{2}{*}{ Mauchly's W } & \multirow{2}{*}{ Approx. Chi-Square } & \multirow{2}{*}{ df } & \multirow{2}{*}{ Sig. } & \multicolumn{3}{|l|}{ Epsilon } \\
\hline & & & & & Greenhouse-Geisser & Huynh-Feldt & Lower-bound \\
\hline factor1 & .446 & 24.294 & 14 & .063 & .750 & .862 & .200 \\
\hline
\end{tabular}

The results in the above table show that the sphercity assumption was not violated $(X 2=24.294, d f=14, p=0.063>0.05)$. Therefore, the results in the following table are safely reported.

Table 5. Tests of Within-Subjects Effects.

\begin{tabular}{|c|c|c|c|c|c|c|}
\hline Source & & Type III Sum of Squares & df & Mean Square & $\mathbf{F}$ & Sig. \\
\hline \multirow{4}{*}{ factor1 } & Sphericity Assumed & 8.967 & 5 & 1.79 & 7.974 & .001 \\
\hline & Greenhouse-Geisser & 8.967 & 3.75 & 2.39 & 7.974 & .001 \\
\hline & Huynh-Feldt & 8.967 & 4.31 & 2.08 & 7.974 & .001 \\
\hline & Lower-bound & 8.967 & 1.00 & 8.96 & 7.974 & .008 \\
\hline \multirow{3}{*}{ Error(factor1) } & Sphericity Assumed & 35.982 & 160 & .22 & & \\
\hline & Greenhouse-Geisser & 35.982 & 120.00 & .30 & & \\
\hline & Huynh-Feldt & 35.982 & 137.91 & .26 & & \\
\hline
\end{tabular}

The results in the first row (Sphericity assumed) show that there was a significant difference between the EFL learners' means on different learning strategies $\left(\mathrm{F}_{(5)}=7.94, \mathrm{p}=0.001<\right.$ $0.05)$. So the second null hypothesis is strongly rejected .Therefore, it could be argued that all learning strategies were not equally used by EFL learners.

The following tables show where the sources of differences are.
Table 6. Within-Subjects Factors.

\begin{tabular}{ll}
\hline factor1 & Dependent Variable \\
\hline 1 & memory \\
2 & cognitive \\
3 & compensation \\
4 & metacognitive \\
5 & affective \\
6 & social \\
\hline
\end{tabular}


Table 7. Paired wise comparison.

\begin{tabular}{lllll}
\hline \multirow{2}{*}{ (I) factor1 } & $(\mathbf{J})$ factor1 & Mean Difference (I-J) & $\begin{array}{l}\text { Std. } \\
\text { Error }\end{array}$ & Sig. \\
\hline \multirow{4}{*}{1} & 2 & -.368 & .091 & .005 \\
& 3 & -.348 & .139 & .259 \\
& 4 & -.646 & .102 & .001 \\
& 5 & -.116 & .091 & 1.000 \\
& 6 & -.455 & .109 & .003 \\
2 & 3 & .019 & .103 & 1.000 \\
& 4 & -.278 & .097 & .109 \\
& 5 & .252 & .107 & .366 \\
& 6 & -.087 & .113 & 1.000 \\
3 & 4 & -.298 & .140 & .610 \\
& 5 & .232 & .131 & 1.000 \\
& 6 & -.106 & .161 & 1.000 \\
4 & 5 & .530 & .108 & .001 \\
& 6 & .192 & .120 & 1.000 \\
5 & 6 & -.338 & .117 & .104 \\
\hline
\end{tabular}

The results of the post hoc test showed that the difference between memory and metacognitive strategies used by Iranian EFL learners is statistically significant $(p=.005<.05)$. Moreover, the difference between memory and metacognitive strategies used by Iranian EFL learners is statistically significant $(p=.001<.05)$. The result also indicated that the difference between memory and social strategies used by Iranian EFL learners is statistically significant $(p=.003<.05)$. Moreover, based on the results of the above table the difference between metacognitive and affective strategies used by Iranian EFL learners is statistically significant $(\mathrm{p}=.001<.05)$.

Q3: Is there any significant difference among the Iranian ESP learners, in terms of employing language-learning strategies?

In order to answer this question, the best statistical procedure was repeated measures one way ANOVA.
The results of repeated-measures one way ANOVA for comparing the mean scores of Iranian ESP learners on learning strategies, and descriptive statistics with related bar graph to provide a visual scene of the topic, are as follows:

Table 8. Descriptive Statistics.

\begin{tabular}{llll}
\hline & Mean & Std. Deviation & N \\
\hline memory & 3.12 & .64 & 33 \\
cognitive & 2.97 & .75 & 33 \\
compensation & 2.83 & .88 & 33 \\
metacognitive & 3.35 & .93 & 33 \\
affective & 2.83 & .78 & 33 \\
social & 3.02 & .98 & 33 \\
\hline
\end{tabular}

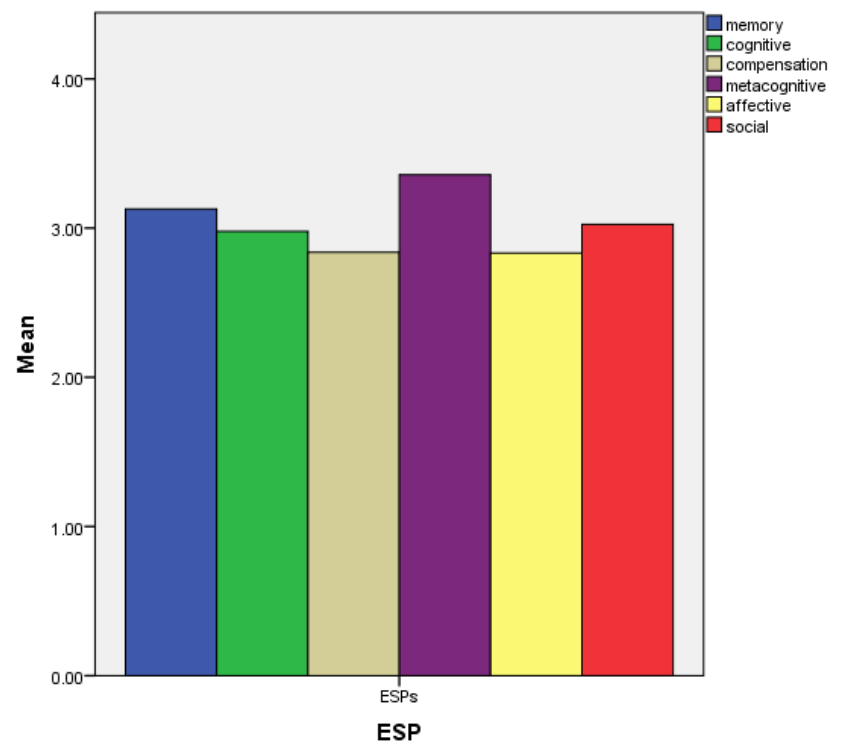

Figure 3. Means of learning strategies for ESP learners.

Table 9. Mauchly's Test of Sphericity ${ }^{a}$.

\begin{tabular}{|c|c|c|c|c|c|c|c|}
\hline \multirow{2}{*}{ Within Subjects Effect } & \multirow{2}{*}{ Mauchly's W } & \multirow{2}{*}{ Approx. Chi-Square } & \multirow{2}{*}{ Df } & \multirow{2}{*}{ Sig. } & \multicolumn{3}{|l|}{ Epsilon $^{\text {b }}$} \\
\hline & & & & & Greenhouse-Geisser & Huynh-Feldt & Lower-bound \\
\hline factor1 & .62 & 14.22 & 14 & .43 & .81 & .94 & .20 \\
\hline
\end{tabular}

As it could be showed in the above table the assumption of the Mauchly's Test of Sphericitya was not violated $(\mathrm{X} 2=14.22$, $\mathrm{df}=14, \mathrm{p}=0.43>0.05)$. Therefore, the results in the following table are safely reported.

Table 10. Tests of Within-Subjects Effects.

\begin{tabular}{|c|c|c|c|c|c|c|}
\hline Source & & Type III Sum of Squares & df & Mean Square & $\mathbf{F}$ & Sig. \\
\hline \multirow{4}{*}{ factor1 } & Sphericity Assumed & 6.418 & 5 & 1.284 & 4.19 & .001 \\
\hline & Greenhouse-Geisser & 6.418 & 4.06 & 1.579 & 4.19 & .003 \\
\hline & Huynh-Feldt & 6.418 & 4.73 & 1.356 & 4.19 & .002 \\
\hline & Lower-bound & 6.418 & 1.00 & 6.418 & 4.19 & .049 \\
\hline \multirow{3}{*}{ Error(factor1) } & Sphericity Assumed & 48.947 & 160 & .306 & & \\
\hline & Greenhouse-Geisser & 48.947 & 130.09 & .376 & & \\
\hline & Lower-bound & 48.947 & 32.00 & 1.530 & & \\
\hline
\end{tabular}

The results in the first row (Sphericity assumed) show that there is a significant difference between Iranian ESP learners' mean scores on different learning strategies $\left(F_{(5)}=6.41, p=\right.$ $0.001<0.05)$.so the third null hypothesis is strongly rejected. 
Therefore, it could be said that all learning strategies were not used by Iranian ESP learners equally. The following table shows where the sources of differences are

Table 11. Within-Subjects Factors.

\begin{tabular}{ll}
\hline factor1 & Dependent Variable \\
\hline 1 & memory \\
2 & cognitive \\
3 & compensation \\
4 & metacognitive \\
5 & affective \\
6 & social \\
\hline
\end{tabular}

Table 12. Paired wise comparison.

\begin{tabular}{lllll}
\hline (I) factor1 & (J) factor1 & $\begin{array}{l}\text { Mean Difference } \\
\text { (I-J) }\end{array}$ & Std. Error & Sig. \\
\hline \multirow{4}{*}{1} & 2 & .150 & .125 & 1.000 \\
& 3 & .290 & .120 & .32 \\
& 4 & -.229 & .125 & 1.00 \\
& 5 & .295 & .138 & .60 \\
& 6 & .103 & .140 & 1.00 \\
& 3 & .140 & .122 & 1.00 \\
& 4 & -.379 & .135 & .12 \\
& 5 & .145 & .115 & 1.00 \\
& 6 & -.047 & .168 & 1.00 \\
3 & 4 & $-.519^{*}$ & .116 & .001 \\
& 5 & .005 & .128 & 1.00 \\
& 6 & -.187 & .146 & 1.00 \\
4 & 5 & $.524^{*}$ & .152 & .02 \\
5 & 6 & .332 & .129 & .22 \\
\hline
\end{tabular}

The results of the post hoc test showed that the difference between compensation and cognitive strategies is statistically significant $(\mathrm{p}=.001<.05)$. The result also showed that the difference between metacognitive and affective strategies used by Iranian ESP learners is statistically significant $(\mathrm{p}=.02<.05)$.

\section{Discussion and Conclusion}

The main objective of the present study was to investigate the use of learning strategies by Iranian EFL and ESP learners. One of the findings of the present study was that EFL learners use all learning strategies more frequently than ESP learners. Therefore, based on the statistical findings provided in result section, it could be strongly argued that difference between EFL and ESP learners in the use of learning strategies is statistically significant. Such a difference might be attributed to different variables such as learners' proficiency in the languages other native language, , age of exposure to language, and the second language interference which need further studies for confirmation.

Moreover, the result of the study indicated that the dominant strategies used by EFL learners were metacognitive, social and cognitive respectively, whereas the most dominant strategies used by ESP learners were metacognitive, memory and social respectively. Therefore it could be argued that, whereas both ESP and EFL learners are reluctant to use metacognitive and social strategies more than other strategies, the bold difference between thus two groups of language learners is memory strategy. While ESP learners use memory strategy more frequently, for EFL learners this strategy is one of the least frequent strategies. Such a difference need further investigation which seems to be beyond the scope of this study.

Furthermore, the result of the present study concluded that both ESP and EFL learners did not make use of all learning strategies equally. Both groups used metacognitive more frequently. Therefore it could be argued that language learners regardless of the status of the language which they learn, need metacognitive strategy for learning effectively. This finding is in a similar vein with Jafari \& Hajizadeh (2012), who argued that the Iranian ESP students used metacognitive strategies significantly more than any other category of strategies. The results also showed that affective and compensation strategies were among the least strategies used by both groups of the participants. This difference in the use of learning strategies by language learners needs further exploration.

Due to the limitation of the study such as sample size and the context of study it could be argued that the finding should be generalized with a great care. And the other researchers are required to replicate the same study with a larger sample.

\section{References}

[1] Brown (2007 Brown, D. H. (2007). Principles of language learning \& teaching. (5th Eds.). Pearson: Longman.

[2] Borzabadi, D. F. (2000). The relationship between language learning strategies and major field of study, sex, language proficiency, and learning style. Unpublished Ph.D. diessertation, Allameh Tabatabaee University.

[3] Chamot, A.U. (2005). Language learning strategy instruction: Current issues and research. Annual Review of applied Linguistics, 25: 112-130.

[4] Cohen (2012), Psychology forlanguage learning: InsighlS From l'eSean:h, theotyandpractice(pp. 136-150). InS. Mercer, S. Ryan, \& M. Williams (2005.) Basingstoke. England: Palgrave Maan Uian.

[5] Cook, V. (2008). Second language learning and language teaching. London: Edward Arnold.

[6] Dörnyei, Z. (2005). The psychology of the language learner. Mahwah, NJ: Lawrence Erlbaum.

[7] Ehrman, M. \& R. L. Oxford. (1990). Adult language learning styles and strategies in an intensive training setting. The Modern Language Journal 74.3, 311-327.

[8] GOH. CHRISTINE C. M Teaching and Learning Second Language Listening: Metacognition in Action. New York: Routledge, 2013.

[9] Grenfell, M., \& Harris, V. (1999). Modern languages and learning strategies: In theory and practice. London: Routledge. 
[10] Hurd, S., \& Lewis, T. (2008). Language Learning Strategies in Independent Settings. Toronto: Multilingual Matters.

[11] Jafari .S \& Hajizadeh, R. (2012) Patterns of Language Learning Strategy Use among Iranian ESP Students. Iranian EFL Journal, 8(5):23-38.

[12] O'Malley, J. M., Chamot, A. U., Stewner-Manzanares, G., Kupper, L.J. \& Russo, R.P. (1985). Learning strategies used by beginning and intermediate ESL students. Language Learning, 35(1): 21-46.

[13] O’Malley, J. M. \& Chamot, A. U. (1990). Learning strategies in second language acquisition. Cambridge: Cambridge University Press.

[14] Oxford, R. L. (1990). Language learning strategies: What every teacher should know. New York: Newbury House/Harper \& Row.

[15] Oxford, R. L. (2003). Language learning styles and strategies: An overview. Learning Styles \& Strategies/Oxford, GALA, 125.
[16] Robin C. Scarcella and Rebecca L. Oxford (1992) Boston, MA: Heinle \& Heinle Publishers.

[17] Wenden, A. \& J. Rubin, (1987). Learner strategies in language learning. Englewood Cliffs, NJ: Prentice Hall.

[18] Oxford, RL 1990a, 'Language learning strategies and beyond: A look of strategies in the context of styles', in Magnan SS (ed.), Shifting the instructional focus to the learner, Middlebury, VT: Northeast Conference on the Teaching of Foreign Languages, pp. 35-55.

[19] Oxford, R.L., 1996a [Marianne - do we remove the "a" here?]: Language Learning Strategies.

[20] Around the World: Cross-cultural Perspectives. Manoa: University of Hawaii Press. 